\title{
Post-theïsme of een andere vorm van theïsme?
}

\begin{tabular}{|c|c|}
\hline $\begin{array}{l}\text { Author: } \\
\text { Gijsbert D.J. D }\end{array}$ & gemans $\mathbf{s}^{1,2}$ \\
\hline $\begin{array}{l}\text { Affiliations: } \\
\text { }{ }^{\text {Department }} \\
\text { Christian Ethic } \\
\text { Theology, Uni } \\
\text { Pretoria, Sout }\end{array}$ & $\begin{array}{l}\text { Dogmatics and } \\
\text { s, Faculty of } \\
\text { ersity of } \\
\text { h Africa }\end{array}$ \\
\hline $\begin{array}{l}{ }^{2} \text { Faculty of Th } \\
\text { Religion, Univ } \\
\text { Groningen, th }\end{array}$ & $\begin{array}{l}\text { ology and } \\
\text { ersity of } \\
\text { Netherlands }\end{array}$ \\
\hline $\begin{array}{l}\text { Research Proje } \\
\text { Project Leader } \\
\text { Project Numb }\end{array}$ & $\begin{array}{l}\text { ct Registration: } \\
\text { : J. Buitendag (1) } \\
\text { er: } 02402343\end{array}$ \\
\hline $\begin{array}{l}\text { Description: } \\
\text { Prof. Dr Gijs D } \\
\text { participating it } \\
\text { project, 'Unive } \\
\text { and Theology' } \\
\text { Prof. Dr Johan } \\
\text { Department o } \\
\text { and Christian } \\
\text { Dean, Faculty } \\
\text { University of P }\end{array}$ & $\begin{array}{l}\text { ngemans is } \\
\text { the research } \\
\text { rsity, Education } \\
\text { directed by } \\
\text { Buitendag, } \\
\text { fogmatics } \\
\text { thics, and } \\
\text { of Theology, } \\
\text { retoria. }\end{array}$ \\
\hline $\begin{array}{l}\text { Correspondin } \\
\text { Gijsbert Dinge } \\
\text { g.dingemans@ }\end{array}$ & $\begin{array}{l}\text { author: } \\
\text { mans, } \\
\text { ziggo.nl }\end{array}$ \\
\hline $\begin{array}{l}\text { Dates: } \\
\text { Received: } 24 \\
\text { Accepted: } 23 \\
\text { Published: } 08\end{array}$ & $\begin{array}{l}\text { Aar. } 2017 \\
\text { pr. } 2017 \\
\text { Dec. } 2017\end{array}$ \\
\hline $\begin{array}{l}\text { How to cite th } \\
\text { Dingemans, G } \\
\text { 'Post-theïsme } \\
\text { vorm van theï } \\
\text { Teologiese Stu } \\
\text { Theological St } \\
\text { a4568. https:/ } \\
\text { 10.4102/hts.V }\end{array}$ & $\begin{array}{l}\text { is article: } \\
\text { D.J., 2017, } \\
\text { of een andere } \\
\text { me?', HTS } \\
\text { dies/ } \\
\text { udies } 73(1) \text {, } \\
\text { /doi.org/ } \\
\text { 73i1.4568 }\end{array}$ \\
\hline $\begin{array}{l}\text { Copyright: } \\
\text { @) 2017. The A } \\
\text { Licensee: AOSI } \\
\text { is licensed und } \\
\text { Creative Comn } \\
\text { Attribution Lic }\end{array}$ & $\begin{array}{l}\text { uthors. } \\
\text { S. This work } \\
\text { ler the } \\
\text { nons } \\
\text { ense. }\end{array}$ \\
\hline Read online & \\
\hline 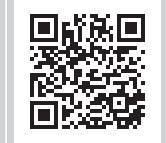 & $\begin{array}{l}\text { Scan this QR } \\
\text { code with your } \\
\text { smart phone or } \\
\text { mobile device } \\
\text { to read online. }\end{array}$ \\
\hline
\end{tabular}

Author:

Affiliations:

'Department Dogmatics and

Pretoria, South Africa

${ }^{2}$ Faculty of Theology and Religion, University of

Research Project Registration: Project Leader: J. Buitendag (1) Description

Prof. Dr Gijs Dingemans is participating in the research and Theology', directed by Prof. Dr Johan Buitendag, Department of Dogmatics and University of Pretoria.

Corresponding author: Gijsbert Dingemans,

Dates:

Received: 24 Mar. 2017 Accepted: 23 Apr. 2017

How to cite this article: Dingemans, G.D.J., 2017, 'Post-theïsme of een andere Teologiese Studies/ Theological Studies 73(1), a4568. https://doi.org/ Copyright:

(c) 2017. The Authors. Licensee: AOSIS. This work is licensed under the Creative Commons Attribution License. mobile device
to read online.
This article examines whether classical theism is at its complete end. In light of current discussions about post-theism in a post-secular age, the question is about the possible search for a new understanding of the idea of God which is compatible with the natural sciences. During 2015 and 2016, symposia about this question were held in Groningen, the Netherlands. From these discussions it emerged that the sharp distinction between 'religious' and 'secular', as well as 'belief' and 'unbelief' has faded. This article will compare and discuss aspects of the contributions of theologians with reference to questions about classical theism and the possible search for a new understanding of the God-idea: Frits de Lange, Taede Smedes, Rick Benjamins, Marcel Sarot and Catherine Keller. These theologians are in search of a post-theistic theism. The article ends with the possibility of another alternative from the perspective of process theology.

Terwijl God niet iets is, betekent dat niet dat God niets is. (Peter Rollins, in De Lange 2016:n.p.)

Er is op het ogenblik een discussie gaande over de vraag naar het zogenoemde post-theïsme in de tijd van het postsecularisme. De vooronderstelling luidt dat enerzijds het traditionele theïsme (God als 'persoon' in een hoge hemel die supernaturalistisch ingrijpt in de wereld) voorbij is en dat we anderzijds inmiddels zijn aangeland in het tijdperk van het postsecularisme, waarin de tegenstelling tussen het religieuze en het seculiere (Benjamins) en tussen gelovig en ongelovig (Smedes) is verzwakt. We zullen dus opzoek moeten naar een nieuw godsbegrip dat liefst ook nog compatibel is met de resultaten van de (natuur)wetenschappen. In Groningen waren er enkele symposia over deze vragen. Ze zijn voor een deel gedocumenteerd in Kerk en Theologie van april 2015 (66/2) met artikelen van Rick Benjamins en Taede Smedes. In 2016 werden er weer lezingen over dit onderwerp gehouden in Groningen die als verslagen van het Groninger Theologisch Werkgezelschap zijn uitgegeven door de leden. De lezing van Frits de Lange uit 2016 is verkort afgedrukt in Trouw van 11 juni 2016. Een eerder - bij het afscheid van Andy Sanders in Groningen - gehouden lezing van Marcel Sarot is afgedrukt in Kerk en Theologie van juli 2013 (64/3). Van Sarot is er vervolgens een lezing uit 2016 waarvan een verslag bestaat bij het Groninger Theologisch Werkgezelschap. In een prachtig boek onder de titel God, iets of niets: De postseculiere maatschappij tussen geloof en ongeloof, zet Taede Smedes de hele discussie rondom het godsbegrip van het post-theïsme op een heldere manier uiteen. Er is ook een interview met hem in Trouw van 20 september 2016 dat op deze vragen ingaat.

\section{Wat verstaan de post-theïsten onder theïsme?}

Taede Smedes spreekt in Trouw (Smedes 2016b) wat badinerend over het theïsme als het 'dubbeldekkermodel' waarbij God losstaat van deze wereld. Hij noemt dat een 'verticale transcendentie' en hij vindt dat een product van de Verlichting (Smedes 2016a:56-63). Volgens Rick Benjamins is het theïsme de opvatting 'die stelt dat God een zelfstandig wezen is, dat ook los van de wereld nog steeds zichzelf is en in de wereld kan ingrijpen'. 'Het post-theïsme is volgens hem het denken dat God niet ziet als de allesbepalende macht in deze wereld die van buitenaf soeverein kan ingrijpen en dus met een theodicee moet worden vrijgepleit van het kwaad in de wereld' (Benjamins 2015:113). Het gaat in deze discussie vooral over de vraag of God (onafhankelijk van de wereld: 'tegenover ons') bestaat of (in en door ons handelen) gebeurt (Hendrikse 2007). Marcel Sarot (2013:205-218) heeft in een voordracht bij het afscheid van Andy Sanders in Groningen duidelijk gemaakt dat het verschil tussen mensen die een 'bestaan' van God onafhankelijk van de wereld verdedigen en mensen die van mening zijn, dat het 'zijn' van God afhankelijk is van ons 'vertrouwen' in God, zodat God zich kan manifesteren, terug gaat op twee inconmensurabele filosofische paradigmata: een 'propositionele' en een 'non-propositionele' benadering. In de eerste benadering gaat het om een objectivistische kentheorie en een realistische 
ontologie; in de tweede om een constructivistische kentheorie en een relationele ontologie. Van het artikel gaat de suggestie uit dat de non-propositionele benadering de beste kentheoretische papieren heeft, maar dat het mogelijk moet zijn er propositionele standpunten in in te bouwen. In een lezing uit 2016, bij een symposium in Groningen over posttheïsme, ${ }^{1}$ typeerde Sarlot het 'theïstische' standpunt dat God 'bestaat' als realistisch en het standpunt, dat God 'gebeurt' als non-realistisch. Zijn eigen standpunt noemde hij toen een 'middenpositie' (Sarlot 2016). Daar kom ik in het vervolg nog op terug.

\section{Wat zijn de problemen met het 'theïsme'?}

\section{Ik citeer Frits De Lange (2016):}

Of God bestaat, ik weet het niet. Ik kan eigenlijk ook niets met die vraag. De theïst zegt 'ja', de atheïst zegt 'nee', de ignost zegt 'ik weet het niet' en de agnost zal zeggen: 'het doet er niet toe'. Ik ben het Voorzienige Opperwezen uit mijn jeugd kwijt, de alwetende God die de touwtjes in handen heeft en met alles zijn Ondoorgrondelijke Bedoeling heeft. Ik blijf ondertussen toch 'Godallemachtig!' roepen bij iets weergaloos moois of huiveringwekkends. En in het onontkoombare appèl dat een ander op mij doet hoor ik iets van een goddelijke verplichting. En ik bid vurig: 'Uw Koninkrijk kome', 'maranatha', met alle mensen die nu een leven van niks leiden en hopen op morgen. Ik zou zonder het woordje God niet kunnen, maar heb wel een heel diffuus godsbeeld. Geloof ik dat God bestaat? Als je daarmee bedoelt of ik het plausibel vindt te veronderstellen dat er voldoende data aanwezig zijn om in te stemmen met het bestaan van een persoonachtig Hoogste Wezen dat het universum bestuurt, zeg ik persoonlijk nee. Ik vind dat godsbeeld ongeloofwaardig, maar heb er ook bezwaren tegen. Ik kan er niet in geloven, maar ik wil het ook niet. Zoals ik het christelijk geloof versta, staat het er ook haaks op ... De God die bestaat komt tegemoet aan een fundamentele behoefte aan veiligheid. Maar niets in de overlevering van Jezus stelt je gerust, dat het allemaal wel goed zal komen. (n.p.)

Als ik samenvat wat de problemen zijn met het theïsme, constateer ik in de eerste plaats dat moderne mensen die leven in een tijd van natuurwetenschappelijk en 'realistisch' denken niet meer kunnen geloven in een God-die-ingrijptin-de-wereld. We kunnen bijna alles wat gebeurt verklaren uit 'innerweltliche oorzaken'. Gods 'almacht' is in elk geval niet proefondervindelijk aantoonbaar en zeker niet vanzelfsprekend. Het oude wereldbeeld (paradigma) van Plato en Aristoteles tot aan Descartes (met een wereld van [goddelijke] ideeën of van de geest [res cogitans] tegenover de tastbare wereld van de materie [res extensa]) is ten einde. We beleven de wereld tegenwoordig vooral als 'zichzelf ontwikkelende materie' en we zoeken naar een nieuwe visie op en verhouding tot de wereld om ons heen. (Materie blijkt inmiddels ook een complex begrip te zijn, dat zelfs 'geest' kan voortbrengen!) Daar komt bij, dat de godsleer na de godsdienstoorlogen van de zestiende en zeventiende eeuw binnen het protestantisme tot een 'rationele constructie', een kille 'godsleer zonder religie' is geworden. Het is een filosofie zonder bezieling. God is zo transcendent - lees: ver weg, boven tijd en ruimte verheven - geworden, dat hij uit de geloofsbeleving is verdwenen (De Boer \& Groot 2013:34, $37,89)$.

Het is daarom ook moeilijk in te zien dat God 'bestaat' zoals de dingen om ons heen bestaan. 'Bestaan' interpreteren we tegenwoordig als 'materieel en tastbaar aanwezig'. We kunnen ons ook een persoon in de hemel moeilijk meer voorstellen. En daarmee hangt samen dat ook het beeld van een persoonlijk God die zich met ieder schepsel afzonderlijk bemoeit aan het verdwijnen is. Sarah Chayes zegt:

De idee van een persoonlijke God heeft me altijd een vorm van hoogmoed geleken, want waarom zou Hij zoveel aandacht aan mij besteden? Ik geloof, dat $\mathrm{Hij}$ ons voordurend allerlei boodschappen stuurt, en dat Hij menselijke boodschappers kiest om die over te brengen. Maar Hij gaat er wel vanuit dat we volwassen zijn en onthoudt zich van het bepalen van onze reacties daarop. (zie Neiman 2008:39)

Secularisatie als afscheid van een persoonlijke, zorgende, in de wereld ingrijpende God is volgens historici en theologen niet alleen het gevolg van de doorwerking van de klassieke oudheid van Plato, Aristoteles en de Stoa, resulterend in de Verlichting van de achttiende eeuw en de tijd van de natuurwetenschappelijke denkwijze, maar ook van 2000 jaar westers christendom. Het christendom staat al vanaf het allereerste begin in het teken van 'ontgoddelijking (van de natuur)' en 'desacralisering van het gewone leven'. 'De secularisatie, die ons het oude godsbeeld uit handen heeft geslagen, is voor een groot deel zelfs de vrucht van het christendom', zegt De Lange Het christendom is 'une religion de la sortie de la religion' (Marcel Gauchet). 'De christelijke boodschap resulteert in een desacralisering van de politiek, gecombineerd met een religieuze opwaardering van het gewone leven'. 'Secularisatie is een dynamiek die in het christelijk geloof ligt opgesloten' (De Lange 2016:n.p.).

Daarom moeten we opzoek naar nieuwe vormen van godsgeloof die passen bij een modern wereldbeeld. Dat gebeurde in Groningen onder het containerbegrip: 'posttheïsme'. Ik meng mij nu - op enige afstand - in deze discussie met een pleidooi voor een 'andere vorm van theïsme'.

\section{Alternatieven die ik afwijs}

Er zijn drie opties die ik a priori afwijs. Dat is het arrogante atheïsme (Smedes 2016a:65-100, 101-150), het even zelfingenomen fundamentalisme, en het naturalisme (Smedes 2016a:151-191). Als theoloog die een leven lang in de christelijke traditie heeft geleefd en gewerkt wijs ik het atheïsme af, evenals het naturalisme van de natuurreligies en van sommige moderne wetenschappers. Ik ben niet alleen door Barth heen gegaan, maar ik kan ook niet meekomen met Spinoza die de natuur met God gelijkschakelde of met natuurwetenschappers die de gang van de evolutie als een soort goddelijke voorzienigheid zien. Ook het zogenaamde bijbelse fundamentalisme heb ik ver achter mij liggen. 
Ik schaar mij liever onder de 'zoekers' die op een nieuwe manier, tastend proberen te denken over de God van de bijbel in een tijd waarin de filosofische en existentiële vooronderstellingen grondig zijn veranderd. Omdat ik daarover al veel vaker heb gepubliceerd (Dingemans 2016; Dingemans \& Smelik 2005) acht ik mij nu van de plicht ontslagen om de argumenten daarvoor nog eens op een rijtje te zetten. Ik kijk nu liever naar de theologen die op zoek zijn naar een posttheïstisch theïsme - om ze zo maar aan te duiden. Ik beperk me daarbij tot de sprekers van de bijeenkomsten in Groningen en de auteurs waarop zij zich beroepen. En ik meng mij - op afstand - in de discussie met een alternatief dat mij al vele jaren bezig houdt: het procesdenken (Dingemans 2000).

\section{Frits de Lange}

Ik begin met het persoonlijke verhaal van Frits de Lange. De titel van zijn artikel luidt: 'En God sprak: Ik besta niet' (2016), ${ }^{2}$ een citaat van Peter Rollins die zichzelf a/theïst noemt:

$[H] \mathrm{ij}$ heeft niks met een God die bestaat. Hij staat een radicaal christendom voor, dat de godverlatenheid van Jezus aan het kruis tot uitgangspunt neemt. 'Mijn God waarom hebt gij mij verlaten?' De God-die-bestaat liet Jezus aan zijn lot over. Het christendom draaide daarna ook nog eens de zaken om: niet de God die bestaat, maar de stervende man aan het kruis, die is God ... Hij wil het trauma van Christus' dood ritualiseren en in zijn transformerende kracht ervaren. (n.p.)

Hoe ziet een geloof eruit zonder religie? Mensen als Rollins proberen er vorm aan te geven, in het spoor van Bonhoeffer, en gevoed door postmoderne denkers als Žižek en Caputo (Smedes 2016a:217-226). Geloof is overgave aan het leven, zonder religieus vangnet. Liturgie is: rituele praktijken bedenken om dat met elkaar te vieren. De liefde maar ook de angst; de hoop maar ook de verslagenheid. Een Opperwezen staat je omarming van deze wereld in de weg. Het ontneemt het leven zijn gratuite karakter. Alles wat er gebeurt ontleent zijn betekenis aan de plek die het inneemt in de goddelijke heilseconomie. Er kan niets gebeuren omdat het nu eenmaal domweg gebeurt. In de religie fungeert God als back-up systeem waarin van elk bestand, ook het meest beschadigde, nog een reserve bestaat. Het geloof in God als garant van de kosmische orde instrumentaliseert het leven. Het ontneemt het zijn contingentie en fragiliteit. De verschrikking en verrukking over een gebeuren dat je zomaar in de schoot geworpen of in de maag wordt gesplitst krijgt geen kans. Het geloof in zo'n God staat, hoe paradoxaal het ook klinkt, het gevoel van waarachtige dankbaarheid in de weg, omdat er altijd weer een directe afzender is die we dankbaar moeten zijn. In zo'n religie gebeuren per definitie ook geen wonderen: zij komen van God, dus zijn ze verklaarbaar. Het geloof in een Master of the Universe out there verhindert om het leven zonder heilseconomie, onvoorwaardelijk, om niet, lief te hebben. (n.p.)

Het feit dat we er zijn, dat we leven, is blijkbaar een kosmische toevalstreffer van jewelste. Een geschenk om niet, om elke dag de hemel voor op je blote knieën te bedanken. Dat we er zijn is eigenlijk godsonmogelijk - en toch zijn we er! Geloof in God moet - zoals de procestheologen dat terecht proberen te doen een plek krijgen in een evolutionair wereldbeeld, waarin alles altijd in beweging is. Als er een God is, dan bestaat hij niet, dan

2.Deze lezing is nog niet gepubliceerd. Ik ontleen de tekst aan het Groninger Theologisch Werkgezelschap. ontstaat, dan wordt hij. Hoe we dat moeten verstaan, een God die niet voorafgaat aan, maar die onderdeel is van de Big Bang, ik weet het niet. Maar dat we geloof in het Opperwezen kwijt zijn is levensbeschouwelijke winst, we gaan minder aan cognitieve dissonantie lijden. (n.p.)

'Omarm het leven', zegt De Lange (2016:n.p.). 'Het leven heeft geen zin, geen doel, anders dan het leven zelf. Het geloof is er om het leven in al zijn chaotische intensiteit, complexiteit, ambiguïteit te ervaren, te vieren, te gedenken. Elke keer als het christendom weer een religie dreigt te worden, moet het zichzelf weer overwinnen en hervinden als herinnering aan dit verhaal, als memoria Christi'. Het christelijk geloof ontspringt aan en leeft van de herinnering aan het religieuze trauma van 'een dode God'. 'Centraal staat in die religie immers een stervende man, die God verwijt dat Hij er niet is'. 'Een religie die op twijfel is gebaseerd, en niet op zekerheid'. 'God bestaat, misschien, bijna niet. Geloof is twijfel'. Met een citaat van Rollins: 'To believe is human, to doubt is divine'. (De Lange 2016:n.p.)

\section{Kanttekeningen}

1. Ik versta het betoog van De Lange als een soort hartenkreet, die ik goed kan begrijpen.

2. Ik ben benieuwd hoe De Lange zich verhoudt tot de kenosistheologie van Gianni Vattimo (2001; 2003a; 2003b).

3. Ik vraag me ook af hoe De Lange zijn stelling van een 'dode God' aan het kruis in overeenstemming brengt met de 'levende God' van de bijbel.

4. Of wordt het geloof bij de Lange een soort levensfilosofie, een naturalistische religie van het leven, waarbij het evangelie (misschien?) de rol speelt van 'existentiële transformatie'?

\section{Taede Smedes}

Ook Taede Smedes heeft afscheid genomen van de verticale transcendentie en een bovennatuurlijke God. In een interview in Trouw (2016) verklaart Smedes sympathie te hebben voor de religieuze atheïsten en religieuze naturalisten (Smedes 2016b). Zij laten zich niets aan theologische doctrines gelegen liggen, maar ze 'maken het leven ... tot uitgangspunt van theologische reflectie' (Smedes 2016a:22). $\mathrm{Bij}$ de mens is volgens hem een transcendentiebesef ingebakken: het besef dat we deel uitmaken van een groter geheel, iets wat ons overstijgt. 'Net als religieuze naturalisten kan ik me hierover enorm verwonderen' (Smedes 2016b:n.p.). Smedes (2016a:260) wijst het religieuze naturalisme uiteindelijk (met Tillich!) af, omdat dan al snel concrete, eindige dingen (als sport of de auto!) het object van ultieme betrokkenheid kunnen worden. Het gaat hem om 'de volheid van het oneindige'. In zijn Groningse lezing citeert hij Einstein, Goodenough, en Raymo, die een grote 'verwondering' ervaren bij het mysterie van het oneindige universum, zodat 'de werkelijkheid zelf ruimte krijgt om heilig te worden' (Smedes 2015). Smedes noemt dat in het interview in Trouw een 'flow', die van buiten komt als hij bijvoorbeeld muziek componeert. Zowel in zijn lezing in Groningen, als ook in zijn boek God iets of niets licht hij dat theologisch toe aan de hand van Schleiermachers Gefühl und Geschmack für das Unendliche en Tillichs dieptedimensie van 
het bestaan. In het interview zegt hij: 'Als je uitgaat van een wereld zonder zin en die daarom zelf creëert, dan blijft zin een eigen constructie zonder autoriteit. Die heeft geen zeggingskracht' (Smedes 2016b:n.p.). 'Wanneer ons transcendentiebesef zou verdrogen, verliezen we bezieling en daarmee een gevoel voor verantwoordelijkheid. Dan houden we een nihilistische samenleving over. En dat is mijn ultieme nachtmerrie' (ibid.). Het gaat niet 'om een systematische theologie, maar om een attitude, een houding tegenover de wereld en, vooral, jegens de medemens' (Smedes 2016a:23). Of met een citaat van Cornelis Verhoeven (1966:202): Het gaat om contemplatie als 'een nietreflecterende vorm van denken, een niet-kiezende vorm van wille, die de mens in staat stelt om met de leegte leven'. En waar richt die contemplatie zich dan naar? Niet naar een voorstelbare godheid of een voorstelbaar hiernamaals, 'maar naar een ongenoemde en onnoembare volheid van zin, die alle beperkte zingeving te boven gaat en daarom als een geschenk uit de leegte verwacht wordt'. 'Het wachten vult de lege ruimte' (Verhoeven 1966:206). 'Een door het mysterie aangeraakte theologie zou de fragmentatie en polarisatie van "geloof" en "ongeloof" en "godgelovige en atheist" kunnen overstijgen door het universele transcendentiebesef in ons aan te spreken'. Geïnspireerd door Christian Wiman (2016) en Paul Pruyser (1976) pleit hij voor een 'bescheiden theologie' (Verhoeven 1966:267) vanuit 'een openbarende gebeurtenis', 'waarin mijn persoonlijkheid, en dus mijn persoonlijk verleden, eveneens een rol speelt' (Verhoeven 1966:269).

\section{Kanttekeningen}

1. Ik deel de verwondering die Smedes beschrijft voor het universum en ik apprecieer zijn poging om boven de tegenstelling 'geloof en ongeloof' en 'godgelovige' en 'atheïst' uit te komen.

2. Ik begrijp en waardeer ook zijn streven om niet alleen met de christelijke traditie in gesprek te blijven, maar er ook deel van uit te blijven maken.

3. Mijn vraag is hoe hij zijn verworven inzichten verbindt met het christelijk geloof. Zowel Schleiermacher als Tillich, op wie hij zich beroept, hebben hun uitgangspunt later ingebracht in een 'systematische theologie'. ${ }^{3}$ Maar misschien is dat teveel gevraagd.

4. Versta ik Smedes goed als ik denk dat hij pleit voor een mystieke vorm van religie (een soort 'negatieve theologie', zoals Dionysius de Areopagiet voorstond?) binnen het christendom die verbindingen kan maken met religieuze atheïsten en naturalisten?

5. Zowel aan Smedes als aan De Lange stel ik de vraag hoe ze hun visie op God in overeenstemming brengen met een 'bijbelse theologie'.

\section{Rick Benjamins}

Ook Rick Benjamins (1964) is een lange weg gegaan. Het begon, na zijn proefschrift over Origenes, met een boek 3.F. Schleiermacher schreef in 1821/1822 zijn Glaubenslehre en P. Tillich schreef van
1951-1963 zijn driedelige Systematic Theology. Dat zijn natuurlijk vruchten van een lange ontwikkeling. getiteld Mocht God bestaan (1997) waarin hij een poging deed het christelijk geloof te verwoorden in een moderne context. In 2003 verscheen Een zachte soort van zijn: drie manieren om van God te denken, met hoofdstukken over Plotinus, Rilke en Jonas. Een zeer brede oriëntatie in de traditie van de moderne theologie ondernam hij in Een en ander (2008). Het is een grondige zoektocht naar de wijze waarop theologen hebben gereageerd op de moderne tijd. Ook in de recente bundel Liberaal christendom vroeg hij zich af 'waar wij ons bevinden, een lokalisatie op de theologische landkaart' en schreef hij drie hoofdstukken over de Geest, Christus en God (Benjamins 2016). In Groningen hield hij in januari 2015 een voordracht onder de titel: 'Na het theïsme en voorbij het secularisme', dat is afgedrukt in Kerk en Theologie (Benjamins 2015:109-121).

In zijn Groningse lezing stelt Benjamins, dat een posttheïstische theologie 'moet proberen het heilige en transcendente in rapport met de tijd ter sprake te brengen en met behulp van de traditie te doordenken' (Benjamins 2015:114). En dat doet hij op basis van het werk van Richard Kearney (2001). Het gaat Kearney niet om een God die al of niet bestaat, maar die 'kan zijn', een posse dat voorafgaat aan esse. God is een 'enabling God', die onze wereld voorziet van mogelijkheden vanuit de toekomst en het is aan de mensen wat ze daarmee doen. En daardoor wordt ook God een door ons geactualiseerde mogelijkheid. In zijn boek Anatheism ${ }^{4}$ (geen theïsme, maar ook geen atheïsme!) zijn zowel het geloof in God als de ontkenning van God reële mogelijkheden en dat geeft hem de kans met beiden in gesprek te gaan. Daarvoor moeten de theïsten ruimte maken voor een kenotische $\operatorname{God}^{5}$ en de atheïsten moeten de mogelijkheid van transcendentie erkennen. En dat kunnen zij doen op grond van een zogenaamde sacramentele verbeelding, dat wil zeggen: de mogelijkheid om het buitengewone (het 'andere') in het gewone waar te nemen en te ontmoeten. De sacramentele verbeelding is een algemeen menselijke wijze van beschouwen. Dit 'andere' wordt vooral ingebracht door de vreemdeling als een belichaming van het transcendente (Benjamins 2015:118). De sacramentele verbeelding is zoiets als een 'heilige epifanie' of 'heiligheid in het alledaagse' (Benjamins 2015:119), te vergelijken met de 'primitieve mentaliteit' (Van der Leeuw), die aan alle mensen eigen is en wijst op een niet-objectiverende beschouwing van de wereld (Benjamins 2015:120). Benjamins besluit zijn lezing met de woorden: 'Die dimensie kan algemeen verstaanbaar zijn en daarmee wordt een terrein geopend voorbij de seculariteit waarin wij kunnen terugkeren tot het heilige of tot God. Die God is geen God van soevereiniteit en theodicee, maar een God, die God is als wij hem God laten zijn' (Benjamins 2015:120).

4.Kearney (2010). Het voorzetsel ana kan 'erboven' en 'opnieuw' aanduiden. Het gaa om de terugkeer van God na de verdwijning van God in momenten van epifanie: het geloof in een God voorbij God (Zie Smedes 2016a:213).

5.De term kenosis (ontlediging) komt zowel bij Vattimo als bij Kearney voor. Bij Vattimo gaat het er om dat God zijn transcendentie aflegt bij de incarnatie (in de mens Jezus) en langzaam verdwijnt uit de geschiedenis, zodat God niet langer 'objectief bestaat', maar alleen gegeven is in 'het boek' (Zie Smedes 2016a:206). Bij Kearney gaat het maar alleen gegeven is in 'het boek' (Zie Smedes 2016a:206). Bij Kearney gaat he
om een God die kan zijn, een God die wellicht, ooit, zal zijn (Smedes 2016a:212). 
In het hoofdstuk 'God laten bestaan' in Liberaal christendom, licht Benjamins (2016d) het bovenstaande toe:

God is de stem waardoor ik mij laat gezeggen, tot goedheid laat bewegen en mijzelf een grens laat stellen. Of die God 'bestaat' en hoe die bestaat weet ik niet. Die stem klinkt namelijk alleen in de zachte stemmen die wij horen ... Wij laten God bestaan, als wij ons laten aanspreken. Datgene waar 'God' voor staat wint aan werkelijkheid in deze wereld, als wij ons er door laten bepalen. Anders dan een God die alles regelt, is dit een God die God is als wij hem God laten zijn. (p. 96)

Je kunt zeggen dat God mogelijkheden geeft of - nog radicaler dat God zelf een mogelijkheid is die keer op keer door de wereld kan worden verwerkelijkt. (p. 97)

Omdat ons iets wordt gevraagd, kunnen wij iets. Omdat wij ertoe worden opgeroepen, zijn we iets. Omdat ons iets wordt toegezegd, gaan wij er over spreken. Je zou dit Gods grote scheppingswerk kunnen noemen: dat hij van ons iets maakt door ons overeind te laten komen. (p. 99)

Hoe verhoudt zich deze visie op God tot de traditionele theologie? Daarvoor gaan we te rade bij het hoofdstuk dat Benjamins in Liberaal christendom schreef over 'Christus, belichaming van God' (Benjamins 2016c:83-91). Uitgangspunt voor Benjamins is dat 'wat boven ons uitgaat, onder ons aanwezig is (dat is het zogeheten 'vertrekpunt' van het boek Liberaal christendom), omdat God onder ons woont (incarnatie). 'God blijft niet op afstand maar is betrokken op en verweven met ons bestaan'. 'In de christelijke traditie vormt Jezus de bepalende aanleiding. In die traditie gaat het over God, zoals hij wordt belichaamd door Jezus' (Benjamins 2016c:85). 'Wat mij betreft is Jezus vooral van belang als een mens die aan God vorm geeft. Hij verhoudt zich tot God, spreekt en handelt namens God en op die manier wordt God een figuur met contouren waartoe wij ons kunnen verhouden' (Benjamins 2016c:86). 'Als belichaming van God brengt Christus heil' (Benjamins 2016c:86), 'doordat hij een verbinding legt tussen mensen en God en zo in gemeenschap laat leven. Je kunt hem een deur noemen waardoor wij binnengaan naar een leven met God'. Jezus Christus is 'het archetype van de mens die leeft met God en daardoor gemeenschap sticht' (Benjamins 2016c:87). Hij geeft in het heden door zijn optreden, zijn genezingen, kritiek en bemoedigingen 'vorm aan het toekomstige rijk van God en verwerkelijkt God op aarde'. Hij 'belichaamt het dubbelgebod van de liefde en daarmee heeft hij een transformerende invloed op mensen' (Benjamins 2016c:88). 'Daarin wordt een nieuwe wijze van bestaan getekend, die nieuwe mogelijkheden opent en transformerend op ons inwerkt'. 'Christus wordt in het evangelie getekend als een mens die vanuit een intieme godsverhouding mensen bejegent en de wereld in een nieuw licht plaatst. Juist daardoor ontstaan nieuwe perspectieven die nieuwe handelingsmogelijkheden openen' (Benjamins 2016c:89). De gemeente van het Nieuwe Testament heeft de historische Jezus beschreven als de Christus, als belichaming van God. ' $\mathrm{Ze}$ is daarmee zelf productief voor de christusidee, waarvoor de historische Jezus aanleiding heeft gegeven ... Zoals Christus vorm geeft aan God, geeft de gemeente vorm aan Christus, die ze in Jezus heeft leren kennen' (Benjamins 2016c:90).
Als Benjamins in het hoofdstuk over de Geest, 'Boven onszelf uitstijgen door de Geest', over de triniteit spreekt, is hij van mening, dat men 'de radicaliteit die in het concept van de triniteit ligt opgeslagen, beter tot uitdrukking [kan] brengen door het accent op de Geest te leggen. Dat is eigenlijk God' (Benjamins 2016b:67). Als ik Benjamins goed begrijp (en niet teveel vanuit mijzelf interpreteer!) werkt de goddelijke Geest 'in algemene zin' door de hele werkelijkheid, 'als wij creatief ingaan op een gegeven situatie' (Benjamins 2016b:64) en tegelijk wordt Jezus door de Geest beleefd als iemand die aanwezig is als hij ons uit het evangelie tegemoet komt en God belichaamt. 'God de Vader wordt waargemaakt door Jezus de Zoon, wiens leven wordt waargemaakt door de Geest' (Benjamins 2016b:67). 'De Geest laat ons de betekenis van Jezus' leven zien op zo'n manier dat wij daardoor worden beïnvloed en op een nieuwe manier in het leven staan' (Benjamins 2016b:66).

Met deze uitvoerige citaten wil ik laten zien, dat en hoe Benjamins de verbinding legt tussen de 'filosofische bespiegelingen over God' en de christelijke traditie - afgezien van de vraag, of men het met deze interpretatie eens is of niet. $^{6}$

\section{Kanttekeningen}

1. Benjamins komt het dichtst bij datgene waarvoor ik ook pleit: de christelijke traditie verwoorden in de context van een postchristelijke en posttheïstische tijd met gebruikmaking van de christelijke traditie.

2. Mij spreekt de 'eschatologische' positie van Kearney aan, ook al is hij 'radicaler' (Smedes 2015:115) dan ik. God 'bepaalt niet', hij 'roept op, zodat mensen (maar ook de natuur, voeg ik daar aan toe) zich op een eigen wijze kunnen ontwikkelen'.

3. Ik heb moeite met een godsbegrip waarin God al te zeer afhankelijk wordt van ons geloof en vooral van onze verbeelding, zodat wij God laten bestaan.

4. In Benjamins bijdrage aan Liberaal christendom ontbreekt een hoofdstuk over de schepping, of - als men wil - de natuur. Ook bij de schepping (voor ons: het begin!) handelt God vanuit zijn toekomst, als hij de dingen tot 'aanzijn' en 'ontwikkeling' roept.

\section{Marcel Sarot}

In zijn lezing heeft Sarot zijn eigen positie als 'middenpositie' nader uiteengezet. ${ }^{7}$ En hij stelt de vraag: 'Geloven wij in een God die onafhankelijk van ons bestaat, of vertrouwen wij in een God die in dat vertrouwen tot aanzijn komt?' Vervolgens somt hij enkele fundamentele (theologische!) bezwaren op tegen het non-realisme waarbij het 'zijn' van God afhankelijk is van ons 'vertrouwen' in God, zodat wij God laten bestaan: het heeft 'geen ruimte voor een handelende God, tenzij in zoverre als wij die handelingen van mensen die evangelische

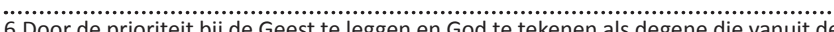
toekomst mogelijkheden schept, lijken mij de overwegingen van Benjamins dicht bij hetgeen te komen dat ik heb bepleit in De stem van de Roepende.

7.Deze lezing is nog niet gepubliceerd. Ik ontleen de tekst aan het Groninger Theologisch Werkgezelschap. 
idealen dichterbij brengen benoemen als handelingen van God' en God wordt de 'diepste grond van ons innerlijk'. Kortom: dan is God geen 'tegenover' meer. En dat is een fundamentele breuk met het traditionele christendom. En toch heeft het realistische ('theïstische') standpunt te weinig oog voor het feit, dat God niet alleen 'de wereld te boven gaat', maar ook 'altijd heel direct aan het binnenwereldse, aan liefde en de dood, gekoppeld moet zijn'. En dat vraagt om 'nieuwe verbindingen tussen immanentie en transcendentie'. Hij citeert Abraham Joshua Heschel die spreekt van een 'transcendente tegenwoordigheid' en hij pleit voor 'de ontwikkeling van een theologie die zowel recht doet aan Gods immanentie als aan Gods transcendentie' (Sarot 2016:n.p.).

\section{Kanttekeningen}

1. Ik begrijp, dat Sarot teruggrijpt op het 'realisme', omdat hij (a) het katholieke geloof wil verdedigen en (b) ten diepste omdat hij zich verzet tegen het subjectivistische ('solipsistische') uitgangspunt van de non-realisten en dus (c) over God wil blijven spreken als een 'tegenover'.

2. Hij vraagt zich af of er niet een nieuwe Thomas van Aquino moet komen die het christelijk geloof kan verwoorden in een nieuwe filosofische taal (Sarot 2013:217). Dat lijkt mij inderdaad een fundamentele opgave voor onze tijd.

3. Mijn vraag is of dat laatste kan met een 'realistische ontologie' of dat theologen moeten zoeken naar een andere (bruikbare!) filosofie. Voor dat laatste pleit ik al vele jaren.

\section{Catherine Keller}

Onder leiding van Rick Bejamins is er in het begin van 2017 in Groningen en Amsterdam een werkgroep actief die het werk van de Amerikaanse theologe Catherine Keller bestudeert en bespreekt.

Catherine Keller is geboren in 1953 en heeft gestudeerd in Claremont en Heidelberg. Ze promoveerde in 1986 bij John Cobb jr., de bekende procestheoloog, en werkte tot 2014 als professor of constructive theology aan de Drew University's Graduate Division of Religion. Ze werd bekend door haar boeken: Apocalypse now and then: A feminist guide to the end of the world (1996), Face of the deep: A theology of becoming (2003), God and power (2005), On the mystery: Discerning God in process (2008) en Cloud of the impossible: Negative theology and planetary entanglement (2015). Ze is in het kader van het post-theïsme van belang, omdat zij een verbinding legt tussen procestheologie, panentheïsme, feministische theologie en de zogeheten 'negatieve theologie' van Dionysios de Areopagiet, Nicolaas van Cusa, Gilles Deleuze etcetera.

In haar boek On the mystery neemt ze haar uitgangspunt in de procestheologie en dat werkt ze uit naar de tijd vóór de schepping in Face of the deep: God schept niet ex nihilo, maar uit de diepte van de tehom (Gen 1:2). De schrijver(s) van Genesis konden niet veel verder kijken dan de aarde en het zichtbare deel van het zonnestelsel ('hemel en aarde'). Het gebruik van het begrip tehom wijst echter op een voor de schepping van onze wereld aanwezige oervloed, een baaierd: 'onze wereld is ontstaan uit de wateren van de oervloed ...' Men moet de tehom niet alleen negatief waarderen, zoals Von Rad doet, maar zowel positief als negatief: het gaat om een oorspronkelijke, positieve scheppingenergie (emergentie, zelforganisatie kan alleen plaats vinden als er energie wordt toegevoegd) èn de afbraak daarvan (entropie, alles vergaat tot chaos, als er geen energie aan wordt gegeven) - leven en dood. Het is de - vooralsnog onpersoonlijke - energie die schept èn vernietigt. Uit die oergrond 'schept' God de wereld door het licht te scheiden van de duisternis.

Zoals er geen absoluut begin is, zo verkondigt de apocalyptiek geen definitief einde. Dat werkt ze uit in haar boek On the mystery en vooral in Apocalypse now and then. Daarvoor moet men de apocalyptiek 'tegen-apocalyptisch' (niet antiapocalyptisch) lezen. Ze spreekt van 'inter-tekst' en verwijst daarvoor naar Allen Boesak en Mary Daly. Het boek Openbaring is een interpretatie van 2000 jaar geleden. Wij kunnen slechts gebruik maken van die teksten als we ze op onze manier interpreteren.

In de discussie in Groningen ging het vooral om de verbinding tussen panentheïsme en de negatieve theologie van Nicolaas van Cusa. Keller is vanuit haar uitgangspunt in de procestheologie van mening dat alles met alles samenhangt en ze neigt er toe om dat het goddelijke te noemen. Alles wat bestaat is opgebouwd uit relaties en ook God is met onze wereld verweven. Alles is in God ingevouwen en God wordt in de wereld uitgevouwen. Maar dan komt de vraag op of dat standpunt niet dicht bij het pantheïsme komt.

\section{Kanttekeningen}

1. Ik waardeer het als positief dat Keller uitgaat van een procesfilosofie die enerzijds de samenhang tussen alle gebeurtenissen (events) serieus neemt en anderzijds de zelfstandigheid van de evolutie erkent. Ik vraag me wel af of je die samenhang 'God' kunt noemen.

2. Ik vind haar scheppingstheologie intrigerend.

3. Ik heb moeite met haar pogingen om de negatieve theologie te integreren in het panentheïsme, omdat dat neigt naar pantheïsme.

4. Ik vind dat ze soms wel erg hardhandig omgaat met bijbelteksten.

\section{Een andere benaderingswijze}

1. Met De Lange en Smedes heb ik al lang geleden afscheid genomen van de Almachtige God die alle dingen regeert. ${ }^{8}$ Ik herken dus heel veel in hun afscheid van het traditionele godsbegrip.

2. Ik ben het met De Lange en Smedes eens dat in ons wereldbeeld het (platoonse) dubbeldekkermodel van een

8.In en door de Tweede Wereldoorlog had ik al veel moeite met de idee van een almachtige God en in de zestiger jaren waren het Harvey Cox (The secular city) en Thomas Altizer (The gospel of Christian atheism) die ons deden zoeken naar een andere kijk op God. 
verticale transcendentie niet meer werkt. Ik pleit daarom ook voor een horizontale transcendentie of een transcendente tegenwoordigheid (Sarot).

3. Ik deel het verlangen van Benjamins om het christelijk geloof op een nieuwe wijze uit te drukken in het kader van een nieuw wereldbeeld en ik deel ook zijn opvatting dat Vader, Zoon en Geest aan elkaar gerelateerd zijn. Ze vormen samen de 'flexibiliteit' of 'beweeglijkheid' van God. In de theologische reflectie moet men daarom de prioriteit bij de Geest leggen.

4. Ik ben het met de godsdienstfilosofen eens dat godsbewijzen weinig meer bewijzen dan het eigen gelijk. Daarom ga ik er liever vanuit dat mensen dat wat hen het diepst raakt en draagt 'God' noemen. Dat kan de Zon zijn, of de Natuur, het 'Onmetelijke' en 'Ongrijpbare' of het eigen diepste ' $\mathrm{Ik}^{\prime}$. Maar men kan ook kiezen voor de bijbelse traditie die laat zien hoe de meegaande God in Israël is gegroeid uit het naturalistische Baälisme en tenslotte gestalte heeft gekregen in profeten en zieners en vooral in het leven van Jezus als de verpersoonlijking van Gods Aanwezigheid. ${ }^{9}$

5. Bij sommige posttheïstische denkers heb ik de indruk, dat ze een nieuwe vorm van religie (al of niet binnen de christelijke traditie) willen ontwerpen die nauwelijks aansluit bij de ontwikkelingen in de huidige theologische bezinning en bij de religieuze beleving van christenen. Daarbij is het uitgangspunt vaak het eigen bewustzijn: dat wat ikzelf belangrijk vind en kan bevatten. Dat heet soms 'relationele filosofie', maar het is een 'religie zonder godsleer' (De Boer \& Groot 2013), een vorm van 'solipsisme' (Sarot): ieder mens en dus ook iedere [godsdienst]filosoof heeft zijn eigen 'God'. Relationele filosofie en theologie zouden - naar mijn overtuiging rekening moeten houden met het feit dat mensen in relatie staan tot de wereld buiten hen, de medemensen en tot een Energie, of Aanwezigheid, die we God plegen te noemen. Ik vind, dat God principieel een 'Tegenover' is. En 'relatie' of 'verbond' houdt een wederzijdse betrekking in.

6. Mijn vraag is of men vanuit een filosofisch standpunt de bijbel recht kan doen. Kan men niet beter vanuit een bijbelse theologie een bijpassende (moderne?) filosofie zoeken?

7. Uitgangspunt van de westerse filosofie is nog steeds het 'zijn'. Benjamins heeft een van zijn boeken Een zachte vorm van zijn genoemd. En De Lange pleit in de genoemde lezing voor 'een evolutionair wereldbeeld, waarin alles altijd in beweging is. Als er een God is, dan bestaat hij niet, dan gebeurt hij', zoals energie en liefde 'gebeuren'. Voor mij betekende dat indertijd - op grond van de bijbelse theologie (!) - een radicale paradigmshift van een 'zijnsfilosofie' naar een 'filosofie van worden of gebeuren' (events, of actual occasions), zoals ik die had leren kennen bij Whitehead. ${ }^{10}$ Dat heeft voor het zicht op 'God' grote invloed: men moet God niet zozeer zien als een bestaande 'entiteit', maar als een 'gebeuren', dat (a) voorafgaat aan

9.Wat mijn bijbelinterpretatie betreft heb ik veel te danken gehad aan Albertz (1992) die de ontwikkelingen binnen de oudtestamentische tijd analyseert.

10.Ik heb indertijd van Alfred North Whitehead geleerd om de wereld niet in zijnscategorieën te vatten, maar in gebeurtenissen (events). onze werkelijkheid als 'stuwkracht of energie' die 'mogelijkheden' schept ('faciliteert'), (b) als een gebeuren in onze werkelijkheid dat zich op verschillende niveaus realiseert en de verschillende lagen in onze wereld een grote mate van vrijheid (en eigen ontwikkeling geeft) en (c) als 'trekkracht van mogelijkheden naar de toekomst'. Ik ben van mening, dat een moderne interpretatie van de bijbelse godsvoorstellingen uitstekend past in een 'bewegingsfilosofie' of 'evolutiekader' (vgl. Dingemans 2014). Het gaat om een God die niet alleen meegaat, maar ook meegroeit met de menselijke geschiedenis.

8. Deze God is niet almachtig, in de zin dat hij/zij alles bepaalt. God heeft zichzelf beperkt ('beschränkt', 'Gott entäußerte sich zugunsten der Welt', Jonas 1987:14) door een kosmos mogelijk te maken met een eigen ontwikkelingsgang en door zich aan mensen te binden die zowel goede als slechte keuzes kunnen maken. Voor christenen heeft hij zich 'ontledigt' in het leven van Jezus die we daarom de Christus zijn gaan noemen.

9. Deze God is machtig, in de zin dat hij/zij een 'lokkend'11 perspectief biedt, een appèl doet op mensen en ze in beweging brengt in de richting van een nieuwe toekomst.

\section{God omvat en doordringt onze werkelijkheid: Een andere vorm van theïsme}

Ik kies dus voor een vorm van theïsme die niet uitgaat van een Master of the Universe, hoog in de hemel, die alle dingen regeert en ieders lot nauwkeurig bepaalt, maar ik beschouw God als een krachtige Energie (Dynamis, Pneuma), die niet alleen de mogelijkheden voor de evolutie heeft gefaciliteerd ('schepping' in het bijbelse jargon), maar ook woning zoekt in mensen en zo op een 'persoonlijke' manier onze geschiedenis beïnvloedt en mensen roept naar zijn toekomst. Ik houd vast aan het begrip 'theïsme' of als men wil: 'panentheïsme', waarbij God meer is dan wij zelf zijn, een 'tegenover' (Sarot) dat ons inspireert en naar de toekomst trekt. Dat is weliswaar een 'Dieu sans l'être' (Marion), een 'God beyond God' (Tillich), een 'transcendente Tegenwoordigheid' (Heschel), maar dat versta ik als een God die onze godsbeelden en filosofische constructies te boven of te buiten gaat en die zich tegelijk in onze werkelijkheid manifesteert. Een God die ons omgeeft en inspireert en roept naar de toekomst. Niet een dwingende, alles bepalende God, maar een lokkende, roepende God die onze eigenheid en eigen wijsheid respecteert en daarvoor zichzelf klein maakt en terughoudend optreedt.

\section{Erkenning Tegenstrijdige belangen}

De auteur verklaart geen financiële of persoonlijke belangen te hebben die hem ongepast kunnen hebben beïnvloed bij het schrijven van dit artikel.

11.De gedachte van een "lokkende', "luring" God ontleen ik aan Whitehead. Vergelijk ook Kearney (2001). 


\section{Literatuurverwijzingen}

Albertz, R., 1992, Religionsgeschichte Israels in alttestamentlicher Zeit, Vandenhoeck \& Ruprecht, Göttingen.

Benjamins, R., 2015, 'Na het theïsme en voorbij het secularisme', Kerk en Theologie 66(2), 109-121.

Benjamins, R., 2016a, 'Waar wij ons bevinden: Een lokalisatie op de theologische landkaart', in R. Benjamins, J. Offringa \& W. Slob (reds.), Liberaal christendom Ervaren, doen, denken, pp. 12-41, Skandalon, Vught.

Benjamins, R., 2016b, 'Boven onszelf uitstijgen door de Geest', in R. Benjamins, J. Offringa \& W. Slob (reds.), Liberaal christendom - Ervaren, doen, denken, pp. 62-71, Skandalon, Vught.

Benjamins, R., 2016c, 'Christus, belichaming van God', in R. Benjamins, J. Offringa \& W. Slob (reds.), Liberaal christendom - Ervaren, doen, denken, pp. 82-91, Skandalon, Vught.

Benjamins, R., 2016d, 'God laten bestaan', in R. Benjamins, J. Offringa \& W. Slob (reds.), Liberaal christendom - Ervaren, doen, denken, pp. 92-101, Skandalon, Vught.

Benjamins, R., Offringa, J. \& Slob, W. (reds.), 2016, Liberaal christendom - Ervaren, doen, denken, Skandalon, Vught.

Caputo, J.D., 2006, The weakness of God: A theology of the event, Indiana University Press, Bloomington.

Chayes, S., 2006, The punishment of virtue, Penguin, London.

De Boer, T. \& Groot, G., 2013, Religie zonder God: Een dialoog, Oratio, Uitgeverij Sjibbolet, Amsterdam.

De Lange, F., 2016, Lezing (niet gepubliceerd), gehouden tijdens 'Mini-symposium Hebben we een boodschap aan post-theïsten?', 25 januari 2016, Groninge Theologisch Werkgezelschap, Groningen (verkort afgedrukt: 'En God sprak: Ik besta niet', in Trouw, 11 juni 2016; https://www.trouw.nl/home/en-god-sprak-ikbesta-niet $\sim 280 a f d 02 /$

Dingemans, G.D.J., 2000, De stem van de Roepende, Kok, Kampen.

Dingemans, G.D.J., 2014, “"Theologie als (her)interpretatie”: Zesentwintig overwegingen', HTS Teologiese Studies/Theological Studies 70(1), Art. \#2608, 1-8. https://doi.org/10.4102/hts.v70i1.2608
Dingemans, G.D.J., 2016, De dragende krachten van onze wereld: Gesprekken en overwegingen over God mens en de natuur, Uitgegeven in eigen beheer.

Dingemans, G.D.J. \& Smelik, P.G., 2005, Deze wereld en God: Modern wereldbeeld en christelijk geloof, Kok, Kampen.

Hendrikse, K., 2007, Geloven in een God die niet bestaat, Nieuw Amsterdam, Amsterdam.

Jonas, H., 1987, Der Gottesbegriff nach Auschwitz: Eine jüdische Stimme, Suhrkamp Taschenbuch 1516, Suhrkamp Taschenbuch Verlag, Sinzheim, Germany.

Kearney, R., 2001, The God who may be: A hermeneutics of religion, Indiana University Press, Bloomington.

Kearney, R., 2010, Anatheism: Returning to God after God, Columbia University Press, New York

Neiman, S., 2008, Morele helderheid, Ambo, Utrecht.

Pruyser, P., 1976, Tussen geloof en ongeloof, Ambo, Utrecht.

Sarot, M., 2013, 'Niet echt gebeurd maar wel waar?', Kerk en Theologie 64(3), 205-218.

Sarot, M., 2016, 'Hebben we een boodschap aan post-theïsten?', Lezing (niet gepubliceerd), gehouden tijdens: 'Mini-symposium', 25 januari 2016, Groninger Theologisch Kerkgezelschap, Groningen.

Smedes, T.A., 2015, 'Post-theïsme als natuurwetenschappelijk credo?', Kerk en Theologie 66(2), 122-133.

Smedes, T.A., 2016a, God, iets of niets: De postseculiere maatschappij tussen 'geloof' en 'ongeloof', Amsterdam University Press, Amsterdam.

Smedes, T.A., 2016b, 'Het geloof van de religieus atheïst', Trouw, 20 september 2016, viewed n.d., from https://www.trouw.nl/religie-en-filosofie/het-geloof-van-dereligieus-atheist $\sim a 46 \mathrm{~d} 2 \mathrm{~d} 4 \mathrm{~b}$

Vattimo, G., 2001, Ik geloof dat ik geloof, Boom, Amsterdam.

Vattimo, G., 2003a, Een zwak geloof, Kok, Kampen.

Vattimo, G., 2003b, Het woord is geest geworden, Kok, Kampen.

Verhoeven, C.W.M., 1966, Rondom de leegte, Ambo, Utrecht.

Wiman, C., 2016, Miin heldere afgrond: Overpeinzingen van een moderne gelovige, vertaald door Willem Jan Otten, Brandaan, Barneveld. 